\title{
Quality characteristics and antioxidant activity of goat milk yogurt with fruits
}

\section{Tatiana Cușmenco, Viorica Bulgaru}

\author{
Technical University of Moldova, Chisinau, Republic of Moldova
}

Keywords:

Yogurt

Fruits

Fermentation

Antioxidant

Polyphenol

Anthocyanin

Vitamin

\section{Article history:}

Received 11.06.2019

Received in revised form

28.11.2019

Accepted 30.03.2020

\section{Corresponding author:}

Tatiana Cusmenco

E-mail:

tatiana.cusmenco@

sa.utm.md

DOI: $10.24263 / 2304-$

974X-2020-9-1-8

\section{Abstract}

Introduction. The aim of the research was to evaluate the physico-chemical, microbiological sensory characteristics and antioxidant potential of goat milk yogurt with fruits.

Materials and methods. The yogurt was prepared from goat's milk with the addition of scald fruits (10\%) of aronia (Chokeberry L., Nero variety), peaches (Prunus persica, variety Moldova), raspberries (Rubus idaeus, Cusma de Guguță variety), strawberries (Fragaria xanassa, Selva variety), apples (Malus domestica variety, Golden). Quality indices and antioxidant potential was determined according to standard methods.

Results and discussions. The added fruits type had a strong impact on the values of titrable acidity and $\mathrm{pH}$. The peache yogurt had a $\mathrm{pH}$ of $4.68 \pm 0.019$. Higher acidity was obtained for raspberry yogurt, $103 \pm 0.076^{\circ} \mathrm{T}$. The amount of dry matter indicates $20.40 \pm 0.45 \%$ in strawberry yogurt. The dry matter content is inversely proportional to the value of the water activity, and maximum values were detected of $0.904 \pm 0.038$ for apples, peaches, raspberries yogurt. The minimum viscosity values were obtained for aronia yogurt, $5450 \pm 4.85 \mathrm{~Pa} \cdot \mathrm{s}$, and maximum for strawberry yogurt $8960 \pm 4.45 \mathrm{~Pa} \cdot \mathrm{s}$. The results obtained for determining the total number of germs in the yogurt are satisfactory, the highest result was for peaches yogurt, $1.8 \log \mathrm{cfu} / \mathrm{ml}$. The maximum amount of lactic acid is in apple yoghurt $7.16 \pm 0.40 \log 10 \mathrm{cfu} / \mathrm{ml}$. No yeasts and molds were detected. Aronia yogurt has the highest total content of polyphenols (187.15 mg GAE $100 \mathrm{~g}^{-1}$ ), anthocyanins $(56.45 / 100 \mathrm{~g})$ and antioxidant activity $(3.9 \%)$, the maximum carotenoid content $0.452 \mathrm{mg} / 100 \mathrm{~g}$ was obtained for peaches yogurt and ascorbic acid $25.77 \mathrm{mg} / 100 \mathrm{~g}$ for strawberry yogurt. Yogurt samples sensory properties show that strawberry yogurt has the best characteristics, obtaining 19.25 points of 20 .

Conclusions. The addition of aronia fruits, strawberries and raspberries and peach positively influences the biological value and the quality indexes of goat milk yogurt with fruits. 


\section{Introduction}

Goat milk and dairy products occupy a significant place in the rational diet of humans, due to their high chemical composition and the easy assimilation of the most accessible animal origin proteins [1]. The nutritional interest for the benefit of goat milk yogurt is generally associated with the biological value, such as proteins, calcium, phosphorus and vitamin $\mathrm{A}, \mathrm{D}$, in a relatively high percentage [2].

The fruits are compatible with dairy products [3]. Harnessing the bioactive potential of biologically active fruit compounds, with health benefits, is constantly expanding, the main purpose being the rational use of these compounds in yogurt [4].

To provide a more acceptable look and mask the specific smell of goat's milk, fruit can be added to the recipes, not only to provide attractive color to the product but exert an antiinhibitory effect, due to the fruits biological components, which could extend the yogurt shelf life, hypotheses also supported by other researchers [5]. Some fruit fillers contain tannins, which react with milk proteins, forming a thick precipitate [6].

The aronia is rich in anthocyanins, minerals, antioxidants and vitamin $\mathrm{C}$, thus contributing to the fortifying of the immune system [7].

Raspberries and strawberries can be substitutes for sweets, containing daily carbohydrate dose for an adult body [8], but also an important portion of fiber and water [9], which helps to clean and moisturize tissues [10].

Peaches are rich in beta-carotene and fiber, especially if they are consumed with shell, and in the composition of yogurt they enhance their benefits for the body [11].

Apple is a particularly valuable food for all ages. Apples contains the main vitamins and mineral salts, substances that give a surplus of vitalizing energy [12].

Processing and obtaining new products can substantially affect the quality and properties of bioactive fruit compounds, and the study of these effects is of fundamental and applicative importance in order to optimize processes and improve the quality of yogurt [13].

The use of aronia, strawberries, raspberries, and other bleached fruits in the manufacture of yogurt is less studied. The scald process can diminish the biological activity and nutritional value of the fruits [14]. In this context it is important to know how the biological value of the scald fruits in combination with the yogurt is highlighted, considering the process of yogurt manufacturing. In addition to the negative effects of heat treatment of fruits, scald also has positive effects: enzymes inactivation, air elimination of tissues, which consequently fixes, maintains and even accentuates the color of the finished products, as well as fixing and preserving vitamins during the following processes [15].

The aim of the research was to evaluate the physico-chemical, microbiological sensory characteristics and antioxidant potential of goat milk yogurt with fruit.

To achieve the goal, the following objectives were proposed:

1. Justification for choosing the fruits of aronia, apples, peaches, strawberries and raspberries;

2. Determining and arguing the quality indices of the yogurt (sensory, physico-chemical and microbiological indices);

3. Determination and argumentation of the antioxidant potential of the yogurts samples. 


\section{Materials and methods}

\section{Preparation of fruits pulp}

Freshly ripened fruits (aronia, apples, peaches, raspberries and strawberries) were gently washed under water and cleaned with an aseptic knife. The fruits were processed by scalding at $95^{\circ} \mathrm{C}$ for 5 minutes, packed in glass jars and stored under optimum conditions.

\section{Preparation of fruit yogurt}

To prepare fruit yogurt the goat milk sample was received from the local goat farm. The goat's milk was pasteurized at $90^{\circ} \mathrm{C}$ for 10 minutes, after which it was cooled to the inoculation temperature. For the yogurt manufacture the Lyofast YAB 352 starter culture was used for inoculation, which contain Streptococcus thermophilus, Lactobacillus delbrueckii subsp. Bulgaricus, Lactococcus lactis subsp Lactis biovar diacetilactis, sucrose and maltodextrin. In the yogurt mixture, the scald fruit pulp was added in $10 \%$ concentration. The samples were thermostated at $37{ }^{\circ} \mathrm{C}$ for 6 hours. The end of the coagulation process was determined by the $\mathrm{pH}$ value and firmness of the coagulum. The yogurt samples were packaged in $180 \mathrm{~g}$ containers and stored at $8 \pm 2{ }^{\circ} \mathrm{C}$.

The yogurt was prepared by the thermostat method, being an effective method to study the formed clot and its firmness [2].

The assortment of yogurt is presented in Table 1.

\section{Assortment of manufactured yogurt}

Table 1

\begin{tabular}{|c|c|c|c|c|c|c|}
\hline \multirow{2}{*}{$\begin{array}{c}\text { Raw } \\
\text { material }\end{array}$} & \multicolumn{6}{|c|}{ Sample } \\
\cline { 2 - 7 } & $\begin{array}{c}\text { Classic } \\
\text { yogurt }\end{array}$ & $\begin{array}{c}\text { Yogurt } \\
\text { with } \\
\text { aronia }\end{array}$ & $\begin{array}{c}\text { Yogurt } \\
\text { with } \\
\text { apple }\end{array}$ & $\begin{array}{c}\text { Yogurt } \\
\text { with } \\
\text { peach }\end{array}$ & $\begin{array}{c}\text { Yogurt with } \\
\text { raspberries }\end{array}$ & $\begin{array}{c}\text { Yogurt with } \\
\text { strawberry }\end{array}$ \\
\hline Goat milk & CY & ArY & ApY & PY & RY & SY \\
\hline
\end{tabular}

\section{Methods}

Titrable acidity determination consists in neutralizing the acidic milk substances with $0.1 \mathrm{n} \mathrm{NaOH}(\mathrm{KOH})$ solution using phenolphthalein as an indicator. The calculation formula is

where: $\mathrm{V}$ - volume used for titration [16].

$$
\text { Acidity }\left({ }^{\circ} \mathrm{T}\right)=10 \cdot \mathrm{V},
$$

pH determination. the $\mathrm{pH}$ value of the milk was determinated using $\mathrm{pH}$ metre (glass electrodes) [16].

Viscosity determination of acid dairy products was determined using the "Brookfield DV - III" rheometer, with indicator no. 04, 250 rotations/min, data were read after 30 seconds of rotations [17]. 
Dry matter content determination. Method use the Radwag MAC moisture analyzer [18]. which consists in IR sample drying on an apparatus aluminum support until a constant mass of the dry residue is obtained.

Water activity determination. It is measured the vapor pressure of the water around the food and divided by the vapor pressure of the pure water to give a value between 0.0 and 1.0 [19].

Fat content determination - made by the acid-butyrometric method and consists in the separation of the fat using isoamyl (amyl) alcohol by centrifuging the milk, previously mixed with sulfuric acid [20].

Determination milk protein content by formaldehyde titration -consists of blocking the proteins amyl groups with formic aldehyde and the release of the carboxylic groups, which are neutralized with $0.1 \mathrm{n} \mathrm{NaOH}$ solution [21].

Determination of the total number of microorganisms, lactic bacteria. The number of bacteria is estimated indirectly, based on the number of colonies generated by the cells of microorganisms after thermostatization at $37^{\circ} \mathrm{C}$, for 48 hours [22, 23].

Determining the number of yeasts and molds. The homogenized samples were diluted in series by adding $1 \mathrm{ml}$ of sample in $9 \mathrm{ml}$ of pepton water, usind agar medium according to the instructions, the result was expressed as colony units per $\mathrm{ml}(\mathrm{CFU} / \mathrm{ml})$ [23].

Determination of total phenolic compounds - estimated according Folin-Ciocalteu method [24]. A volume of $1 \mathrm{ml}$ of methanolic extract of each sample was added to $1 \mathrm{ml}$ of Folin-Ciocalteu's solution in a test tube. After 3 minutes, $1 \mathrm{ml}$ of $20 \%$ sodium carbonate solution was added to the mixture and adjusted to $10 \mathrm{ml}$ with distilled water. The mixture was allowed to stand at room temperature in a dark environment for $30 \mathrm{~min}$. Absorbance was measured against the blank reagent at $725 \mathrm{~nm}$. Gallic acid was used for the calibration curve with a concentration range of $50-1000 \mu \mathrm{g} \cdot \mathrm{mL}^{-1}$. Results were expressed as $\mathrm{mg} \mathrm{GAE} \cdot 100 \mathrm{~g}^{-1}$.

Determination of anthocyanin content was measured by spectrophotometric method at $540 \mathrm{~nm}$, extracted with a solution of $95 \%$ ethyl alcohol and $1.5 \mathrm{n} \mathrm{HCl}$ to discoloration [25].

Antioxidant properties was determined by using a platinum and silver electrodes pattern model B90417 AVL - 1M the thermostatic cell, according to SM EN 12857:2014 [26].

Vitamin C - prepared extract titration with $0.001 \mathrm{~N}$ indicator solution of 2,6 diclorfenolindofenol [27].

Carotenoids determination - the method is based on the photometric determination of the mass carotene concentration in the solution obtained after the carotenoids extraction with an organic solvent and purified of the accompanying substances using dye by column chromatography [28].

Sensory quality assessment based on the score scale. Evaluation of each sensory characteristic by comparison with score scales and obtaining the average score of the tasting 
group [29]. The mean score of the sensory analysis was passed in the centralized results sheet. The average of the total score is calculated based on the weighted average scores. Except for the control sample, the yogurt assortment was evaluated as "very good" and characterized as follows: "Product with pleasant, specific, well defined sensory characteristics, does not present any noticeable defects".

$$
P_{m p}=P_{m n p} \times f_{p}
$$

where: $P_{m n p}-$ unweighted average score (the arithmetic average of the results);

$f_{p}$ - the weighting factor (shows how much a sensory characteristic participates in the total sensory quality of the product).

$$
P_{t p}=\sum P_{m p}
$$

Statistical analysis. The variance analysis of the results was carried out by least square method with application of Student test. The differences were considered statistically significant if probability was greater than $95 \%$ (p-value <0.05). All assays were performed in triplicate. The experimental results are expressed as average \pm SD (standard deviation).

\section{Results and discussions}

\section{Analysis of the yogurt samples physico-chemical indices}

Table 2 presents the composition of goat milk yogurt samples. The values obtained for fat and protein content were slightly influenced by the addition of fruits [30]. The protein content of yogurt changes with the incorporation of strawberry, raspberry and peach. The fat content is lower in the yogurt samples, compared to the control sample, possibly due to the increase of water content in the product with the fruits addition, also it should be mentionedthe fruit low fat content. Similar observations were obtained by [31].

Composition of goat milk yogurt samples

Table 2

\begin{tabular}{|c|c|c|c|c|}
\hline Nr. & Sample & Fat content, \% & Protein content, \% & Dry matter, \% \\
\hline 1. & CY & $3.4 \pm 0.035$ & $6.03 \pm 0.052$ & $16.03 \pm 0.42$ \\
\hline 3. & ArY & $2.0 \pm 0.032$ & $5.31 \pm 0.049$ & $17.20 \pm 0.49$ \\
\hline 4. & ApY & $2.6 \pm 0.038$ & $5.14 \pm 0.051$ & $18.93 \pm 0.45$ \\
\hline 5. & PY & $2.4 \pm 0.040$ & $5.43 \pm 0.047$ & $18.73 \pm 0.51$ \\
\hline 6. & RY & $2.3 \pm 0.039$ & $5.62 \pm 0.050$ & $19.11 \pm 0.50$ \\
\hline 7. & SY & $2.1 \pm 0.037$ & $5.51 \pm 0.048$ & $20.40 \pm 0.45$ \\
\hline
\end{tabular}

The dry matter plays an important role in forming the texture of the finished product [32]. The addition of fruits in yogurt significantly influenced the total dry matter content. The dry matter content of fruit yogurt has decreased with the fruits addition, due to the high content of water contained in fruits which significantly increases in the process of scald fruit. Similar observations were reported by [33], who found that the total dry matter content decreased with the addition of fruit.For strawberry yogurt, the highest content of dry matter was obtained $20.40 \pm 0.45 \%$. 
Table 3 presents the physico-chemical indices of yogurt samples. The acidity of a food product is one of the first quality indices that demonstrate its freshness [34]. Acidification of the milk leads to the destruction of the internal structure of the casein micelle due to the solubilization of $\kappa$-casein [35], as a result of acid coagulation, resulting in the formation of the lactic gel. The type of added fruit had an impact on the values of titrable acidity and $\mathrm{pH}$. Higher acidity values $\left(103^{\circ} \mathrm{T}\right)$ were obtained for the raspberry yogurt. The lowest values were obtained for the yogurt with aronia, $94{ }^{\circ} \mathrm{T}$. A similar observation was reported by [36], who reported that the acidity of the yogurt increased due to the type of added fruit.

Table 3

Physico-chemical indices of yogurt samples

\begin{tabular}{|c|c|c|c|c|c|}
\hline Nr. & Sample & Titrable acidity, ${ }^{\mathbf{o}} \mathbf{T}$ & $\mathbf{p H}$ & $\mathbf{a}_{\mathbf{w}}$ & Viscosity, Pa·s \\
\hline 1. & CY & $90 \pm 0.073$ & $5.06 \pm 0.015$ & $0.895 \pm 0.029$ & $5090 \pm 4.54$ \\
\hline 3. & ArY & $94 \pm 0.075$ & $4.65 \pm 0.018$ & $0.901 \pm 0.035$ & $5450 \pm 4.85$ \\
\hline 4. & ApY & $95 \pm 0.071$ & $4.62 \pm 0.016$ & $0.904 \pm 0.038$ & $7650 \pm 4.12$ \\
\hline 5. & PY & $98 \pm 0.078$ & $4.68 \pm 0.019$ & $0.904 \pm 0.038$ & $8500 \pm 4.19$ \\
\hline 6. & RY & $103 \pm 0.076$ & $4.61 \pm 0.015$ & $0.904 \pm 0.038$ & $8640 \pm 4.38$ \\
\hline 7. & SY & $98 \pm 0.075$ & $4.67 \pm 0.011$ & $0.903 \pm 0.030$ & $8960 \pm 4.45$ \\
\hline
\end{tabular}

Water activity $\left(\mathrm{a}_{\mathrm{w}}\right)$ can participate in various chemical and biochemical reactions (eg Maillard reaction) that can affect the nutritional value of the yogurt, in terms of decreasing the storage time. If the water activity value is in the range $0,8-1$, the product is slightly perishable with the risk of rapid development of microorganisms [37], for which minimum values of $0.895 \pm 0.029$ were detected in the control sample and maximum values of $0.904 \pm 0.038$ for apples, peaches, raspberries yogurt.

Yogurt is a soft solid product, and its network is a relative dynamic system, inclined towards rearrangement. The physical properties of yogurt can be explained using the model of interactions in casein micelle that includes the balance between attraction and rejection forces [38]. Rheological properties are important indicators of the quality of the yogurt. The samples were investigated at a temperature of $15^{\circ} \mathrm{C}$, the viscosity depends directly on the sample temperature [39]. This behavior is typical for non-newtonian liquids and is clearly highlighted for fruit yogurt samples. The minimum viscosity values were obtained for the control sample $5090 \pm 4.54 \mathrm{~Pa} \cdot \mathrm{s}$, followed by the aronia yogurt $5450 \pm 4.85 \mathrm{~Pa} \cdot \mathrm{s}$, apple yogurt $7650 \pm 4.12 \mathrm{~Pa} \cdot \mathrm{s}$, peache yogurt $8500 \pm 4.19 \mathrm{~Pa} \cdot \mathrm{s}$, raspberries yogurt $8640 \pm 4.38 \mathrm{~Pa} \cdot \mathrm{S}$, strawberrie yogurt $8960 \pm 4.45 \mathrm{~Pa} \cdot \mathrm{s}$.

\section{Analysis of the yogurt samples microbiological characteristics}

The use of starter culture favors obtaining fermented dairy products. In the process of lactic fermentation, under the influence of the starter culture bacteria, the conversion of lactose into lactic acid occurs [40], which leads to some changes in the manufactured product: the $\mathrm{pH}$ decreases to the isoelectric point of the proteins (4.6), during the reduction of $\mathrm{pH}$ begins the process of forming the gel network specific to fermented milk [41]. On the other hands, biologically active fruit substances can catalyze oxidation reactions, thus being added to the yogurt composition could serve as a natural preservative, contributing to the pathogenic bacteria inhibition [42]. 
Microbiological characteristics of yogurt samples

\begin{tabular}{|c|c|c|c|c|}
\hline \multirow{2}{*}{ Nr. } & Sample & $\begin{array}{c}\text { Total number } \\
\text { of microorganisms, log cfu/ml }\end{array}$ & $\begin{array}{c}\text { Lactic bacteria } \\
\text { (log10CFU/ml) }\end{array}$ & $\begin{array}{c}\text { Yeast } \\
\text { and mold }\end{array}$ \\
\hline 1. & CY & 2.1 & $7.22 \pm 0.03$ & \\
\cline { 1 - 4 } 3. & ArY & 1.5 & $7.16 \pm 0.40$ & \\
\cline { 1 - 4 } 4. & ApY & 1.7 & $7.05 \pm 0.01$ & \multirow{2}{*}{ Absence } \\
\cline { 1 - 4 } 5. & PY & 1.8 & $7.08 \pm 0.03$ & \\
\cline { 1 - 4 } 6. & RY & 1.7 & $7.14 \pm 0.01$ & \\
\hline 7. & SY & 1.6 & & \\
\end{tabular}

The microbiological characteristics of yogurt samples is presented in Table 4. The highest total number of microorganisms was obtained for the peach yogurt sample (1.8 log $\mathrm{cfu} / \mathrm{ml})$, the highest number of lactic bacteria $(7.16 \log 10 \mathrm{cfu} / \mathrm{ml})$ was obtained for the aronia yogurt sample and the smallest value $(7.05 \log 10 \mathrm{cfu} / \mathrm{ml})$ for the apple yogurt sample. Similar findings were also reported by [43], who stated that the number of lactic bacteria increases optimally in slightly acidic conditions when the $\mathrm{pH}$ is between 4.5 and 6.4.[44].

No yeasts and molds were detected.

\section{Antioxidant potential of the yogurt samples}

Yogurt in combination with fruits has a functional role in the human body, due to the supply of fiber, vitamins, minerals, phytonutrients, polyphenols, anthocyanins [45]. The incorporation of processed fruits into yogurt is a popular approach to increase the phenolic content and improve the antioxidant profile. Fortifying yogurt with naturally antioxidants also responds to consumers' demands for "clean label" foods [46, 47].

Some fruits, such as aronia, are good sources of phenolic compounds, especially anthocyanins. Polyphenols are known to interact with milk proteins and form insoluble complexes that reduce the total free polyphenol content [48].

The content of total polyphenols, anthocyanins, ascorbic acid, carotenoids, antioxidant properties of yogurt samples are shown in Figure 1-6. There were significant differences between the samples. The aronia yogurt had the highest polyphenol content $(187.15 \mathrm{mg}$ GAE $100 \mathrm{~g}^{-1}$ ). Peacheand apple yogurt recorded the following values for the total polyphenols content: $184.15 \mathrm{mg} \mathrm{GAE} 100 \mathrm{~g}^{-1}$, respectively $173.93 \mathrm{mg}$ GAE $100 \mathrm{~g}^{-1}$.

Due to antioxidant properties, anthocyanins play an important role in determining the color of fruit yogurt and differ from other compounds due to their ability to form different structures depending on the $\mathrm{pH}$ of the environment. Due to this property, anthocyanins can offer the body, protection against the intense harmful reactions of free radicals and can be used in the manufacture of yogurt as natural dyes [49]. In addition to their coloring properties, anthocyanins exhibit a wide range of biological activity, including antimicrobial, antimutagenic, anticancer, antitumor and antioxidant activities [50]. Anthocyanins are important, being the alternative of synthetic dyes, are considered safe because they have been consumed for centuries in fruits and vegetables without any health risk [51]. 


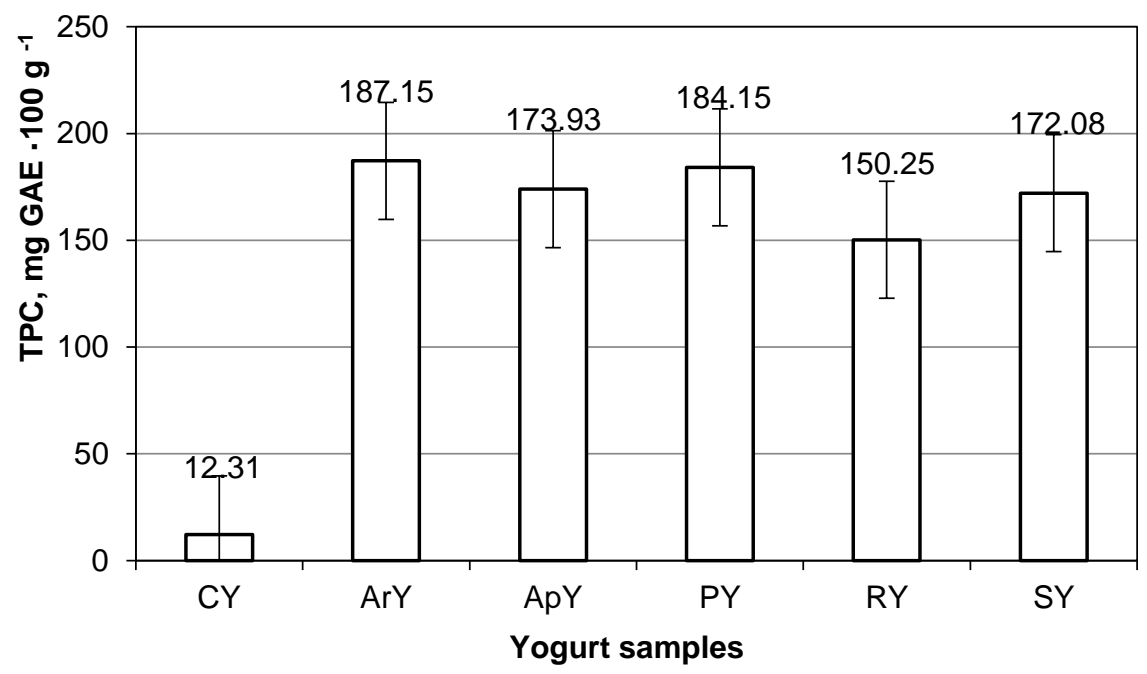

Figure 1. Total polyphenol content of yogurt samples

Using a simple method for quantifying total monomeric anthocyanins, the content of anthocyanins in fruit yogurt was determined. Values ranged from $19.36-56.45 \mathrm{mg} / 100 \mathrm{~g}$ (Figure 2). The highest content of anthocyanins was in aronia yogurt $(56.45 \mathrm{mg} / 100 \mathrm{~g})$, followed by the raspberry yogurt $(48.34 \mathrm{mg} / 100 \mathrm{~g})$, the strawberry yogurt $(40.47 \mathrm{mg} / 100 \mathrm{~g})$. low value was obteind for apple yogurt $(19.36 \mathrm{mg} / 100 \mathrm{~g})$.

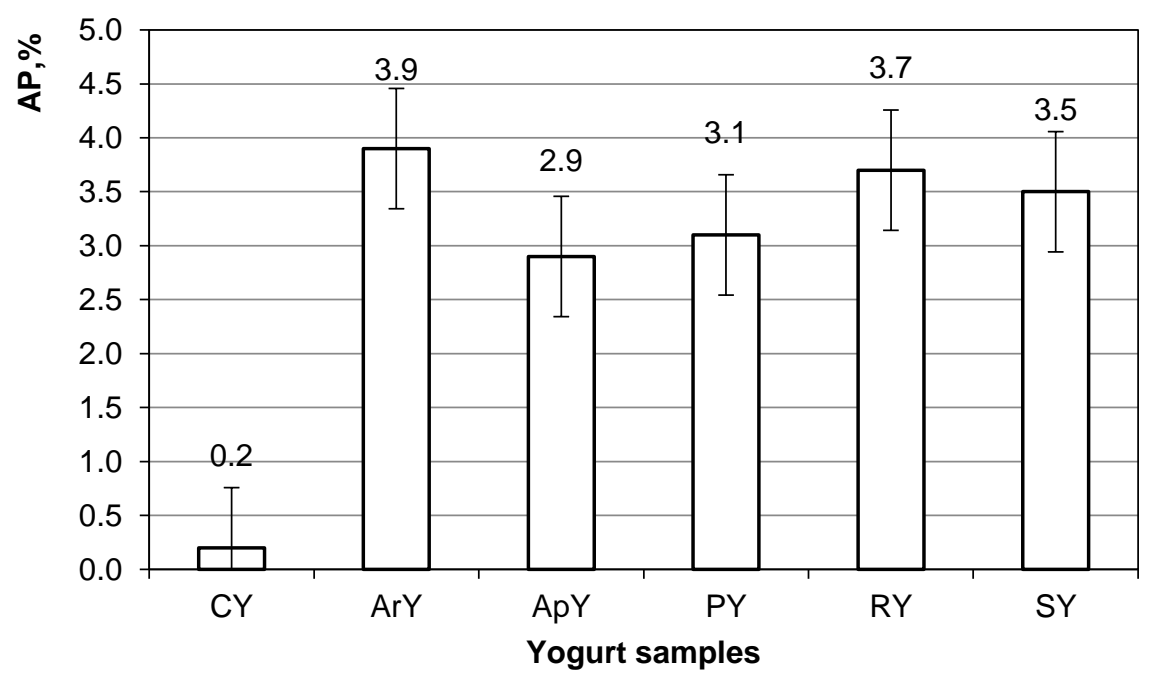

Figure 3. Antioxidant properties of yogurt samples 
Antioxidants are bioactive substances that prevent oxidation reactions promoted by oxygen or peroxides and thus protect cells from the oxidative stress effect [52]. Fruits are a natural source of antioxidants and therefore their effectiveness in protecting against oxidative stress has been demonstrated by some researchers [53].

Natural antioxidants with a positive effect on oxidative stability have the role of preventing rancing [54], an undesirable fact in the obtained yogurt samples. Aronia yogurt registered the highest antioxidant property of $3.9 \%$, followed by raspberries $(3.7 \%)$ and strawberries $(3.5 \%)$ yogurt.

There are numerous data [55] that show that fruits can provide more vitamins, more important beeind vitamin C (Figure 4) and $\beta$-carotene (Figure 5) [56].

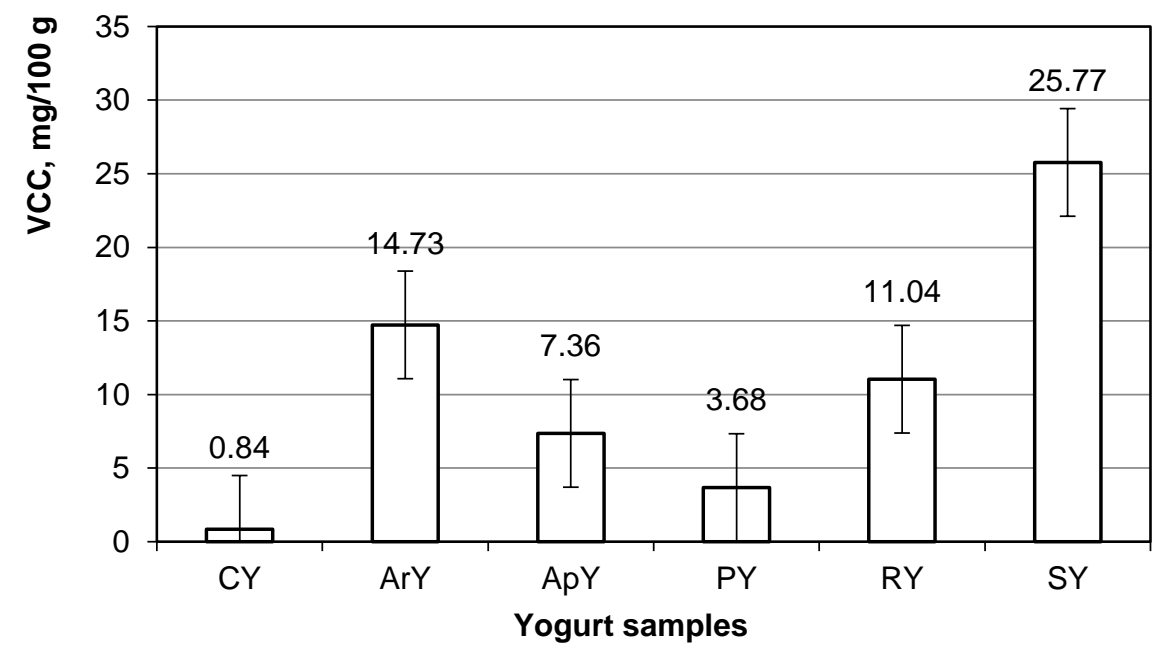

Figure 4. Vitamin C content of yogurt samples

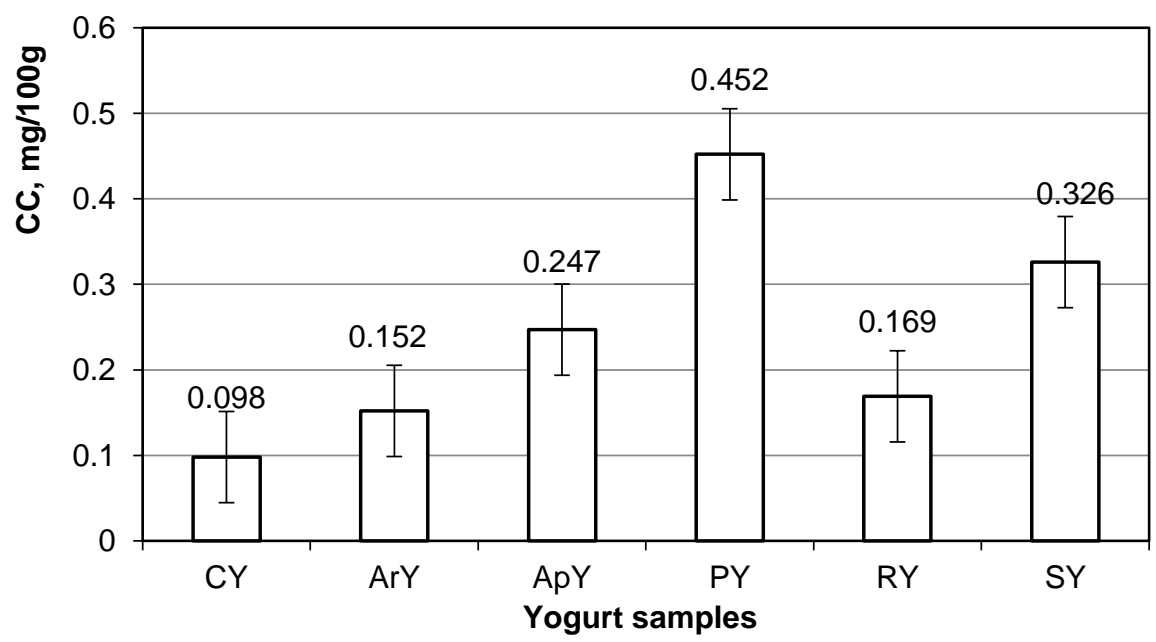

Figure 5. Carotenoids content of yogurt samples 
The vitamin C content of the fruit yogurt samples ranges from 3.68 to $25.77 \mathrm{mg} / 100 \mathrm{~g}$. The strawberry yoghurt had the highest value $(25.77 \mathrm{mg} / 100 \mathrm{~g})$, results discussed also by [57].

Carotenoids are a natural antioxidant that is present in yellow and green vegetables and fruits [58]. As a plant-based antioxidant, carotenoids can control the excess formation of free radicals and increase the capacity of antioxidants, as well as replace synthetic carcinogens that cause liver damage. Carotenoids, for example, are located in the membranes of fat globules, where they prevent the automatic oxidation of fat [59].

The carotenoid content ranged between $(0.152-0.452 \mathrm{mg} / 100 \mathrm{~g})$ peach yogurt had a maximum value. Similar results were reported by [60].

\section{Analysis of the sensory characteristics of the yogurt samples}

The characteristics of the sensory quality are the parameters appreciated by the consumers, being the most important factor in determining the acceptance of food products [61]. The sensory properties of fermented dairy products should be examined in the following order: appearance and consistency, taste and smell, color $[62,63]$. The results of the sensory evaluation are shown in Figure 6.

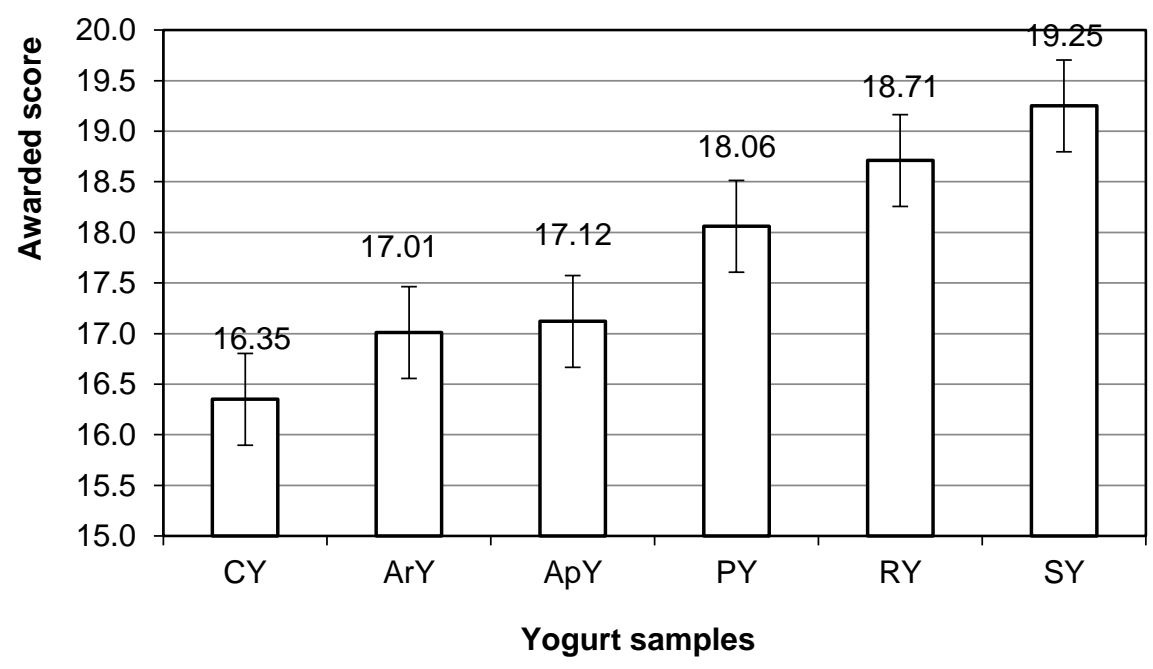

Figure 6. Total point average of the yogurt samples.

According to the results of the sensory analysis, the strawberry yogurt sample obtained the highest score, 19.25 points of 20; followed by raspberry yogurt, similar results being obtained by [64].

\section{Conclusion}

1. Goat milk due to its curative properties, high digestibility, technological properties (high quality of the formed coagulum) is a recommended row material in yogurt fabrication.

2. High biological value, antibacterial properties of fruits used as additives make the end product - goat milk yogurt with fruits - safe functional food for consumption.

3. The addition of scald fruit improved the yogurt quality index, compared to the control sample, positively influencing the content in bioactive compounds. 
4. In the yogurt samples with aronia fruits, there was a significant increase in the content of polyphenols, anthocyanin's, antioxidant properties compared to other samples.

5. Strawberry yogurt obtained the highest values for sensory characteristics and the vitamin C content.

6. Peach yogurt has an important content of carotenoids and polyphenols.

\section{References}

1. Sandulachi E., Bulgaru V. (2019), Factor affecting quality of goat's milk yoghurt, Advances in social sciences research journal, 6(2), pp. 205-221.

2. Gomez-Gallego C., Gueimondem R., Sallminen S. (2014), The role of yogurt in food based dietary guidelines, Nutrition reviews, 76, pp. 29-39.

3. Ghendov-Moșanu A. (2018), Compuși biologic activi de origine horticolă pentru alimente funcționale, Editura Tehnica- UTM, Chişinău, pp. 35-41.

4. Domagaia J., Juszczak L. (2004), Flow behavior of goats milk yoghurts and bio yoghurts, Food Science and Technology Electronic Journal of Polish Agricultural Universities, 7(2), pp. 63-74.

5. Caunii A., Cuciureanu R., MiklósnéZakar A., Tonea E., Giuchici C. (2010), Relationship of chemical composition to quality in vegetables, Studia Universitatis "Vasile Goldis", Life Sciences Series, 1, pp .85.

6. Butnariu M. (2007), Noțiuni teoretice şi practice de biochimie vegetală, Timişoara, 1, pp. 158.

7. Gahruie H.H., Eskandari M.H., Mesbahi G., Hanifpour M.A. (2015), Scientific and technical aspects of yogurt fortification: a review, Food Sci Hum Wellness, 4, pp. 1-8.

8. Liang C. et al. (2013) Phytochemical properties and antioxidant capacities of commercial raspberry varieties, Journal of Functional Foods, 5(1), pp. 508-515.

9. Hruskar M., Krpan M., Bucak I., Vahcic N. (2005), Concentration changes of aroma components in plain and probiotic yoghurt during storage, Mljesartvo, 55 (2), pp. 25-31.

10. Mei J.B., Reineccius G.A., Knighton W.B., Grimsrud E.P. (2004), Influence of strawberry yogurt composition on aroma release, Agric Food Chem, 52(20), pp. 85-91.

11. Yuyama L., Aguiar J., Yuyama K., Clement C., Macedo S., Favaro D., Alfonso M, Casconsellos M., Pimentel S., Badolato E. and Vannucchi H. (2003), Chemical composition of the fruit mesocarp of three peach palm (Bactrisgasipaes) populations grown in Central Amazonia, Brazil, Int J Food SciNutr, 85, pp. 1505-1512.

12. Harsan E., Sestras R., Somsai P., Barbos A. and Sestras A. (2006), Research Regarding the Principal Chemical Component Loss in the Apple Fruit during Storage, Notulae Botanicae Horti AgrobotaniciCluj-Napoca, 34, pp. 106-114.

13. Granato D., Branco G.F., Cruz A.G., Faria J., Shah N.P. (2010), Probiotic dairy products as functional foods, Compr Rev Food Sci Food Saf, 9, pp. 455-470.

14. Vahedi N., Tehrani M. M. and Shahidi F. (2008), Optimizing of fruit yoghurt formulation and evaluating its quality during storage, Am-Euras. J. Agric. and Environ, Sci, 3(6), pp.922-927.

15. Di Cagno R., Coda R., De Angelis M, Gobbetti, M. (2013), Exploitation of vegetables and fruits through lactic acid fermentation, Food Microbiol., 33, pp. 1-10.

16. Masulli D. (2016), Measuring pH and titrable acidity of yogurt, Food Quality \& Safety, 4, pp.651662.

17. Brookfield DV3T Viscometer Operating Instructions Manual, pp. 7.

18. Sturza R. (2016), Principii moderne de analiză a alimentelor, Monografie, Chișinău, 1, pp. 81.

19. Powitz R.W. (2007),Water activity: a New Food Tool, Sanitarin's file, 1, pp. 125.

20. Walker R.W., Goran M.I. (2015), Laboratory determined sugar content and composition of commercial infant formulas, baby foods and common grocery items targeted to children, Nutrients, 1, pp. 98-105.

21. Pyne G. T., Determination of milk proteins content by formaldehyde titration, Department of Dairy Chemistry, University College, 26 (4), pp. 14. 
22. Hassan A., Amjad I., Mahmood S. (2009), Microbiological and physicochemical analysis of different UHT milk available in a local market, As. J. Food Ag-Ind., 2(03), pp. 434-447.

23. Sandulachi E., Bulgaru V. (2019), Microbiologia industrială, Îndrumar metodic, Editura „Tehnica - UTM”, pp. 25-28.

24. Prior R. L., Xianli Wu., Schaich K. (2005), Standardized Methods for the Determination of Antioxidant Capacity and Phenolics in Foods and Dietary Supplements, J.Agric. Food Chem, 53(1), pp. 4290-4302.

25. Tanchev A. D. (1980), Anthocyanins in fruits and vegetables, Food processing industry, pp. 304.

26. Macari A., Tatarov P., Sandulachi E. (2005), Determination of antioxidant activity of vegetables by potentiometric method, Papers of the International Symposium „Euro-aliment”, România, pp. $12-15$.

27. Morrissey P. A. (2002a), Vitamins|Vitamin C, Nutritional Significance. În R. Editor-în-Chief: Hubert (Ed.), Encyclopedia of Dairy Sciences, pp. 2683-2690.

28. Randoin L., Perroteau A. (1990), Estimation of the vitamin C, A, B1 and riboflavin contents of different human milks and a study of their modification during sterilisation and conservation at the milk centre. Lait, 30, pp. 622-629.

29. Necula V. (2010), Analiza senzorială a alimentelor, Note de curs, pp. 2-4.

30. Mohammad A. M. S. and Mohammad O. Mohammad A. (2017), Physico chemical and sensory characteristics of stirred yoghurt flavored with mango (mangiferaindica L.) fruit during storage period, Pak.J.Nutr., 16, pp. 378-383.

31. Haque A., Richardson R. and Morris E. (2001), Effect of fermentation temperature on the rheology of set and stirred yogurt, Food Hydrocoll., 15, pp. 593-605.

32. Sodini I., Remeuf F., Haddad S. and Corrieu G. (2004), The relative effect of milk base, starter, and process on yogurt texture: a review, Crit. Rev. Food Sci. Nutr., 44, pp. 113-137.

33. Gonzalez-Martinez C., Becerra M., Chaffer M., Albors A., Carot J.M. (2002), Influence of substituting milk powder for whey powder on yogurt quality, Trends Food Sci. Technol., 13, pp. 334-340.

34. Bartoo S.A, Badrie N. (2005), Physicochemical, nutritional and sensory quality of stirred dwarf golden apple (Spondias cytherea Sonn) yoghurts, Int J F Sci Nutr., 56(6), pp. 445-540.

35. Chee C.P., Gallaher J.J., Djordjevic D., Faraji H., McClements D.J., Decker E.A., Hollender R., Peterson D.G., Roberts R.F., Coupland J.N. (2005), Chemical and sensory analysis of strawberryflavoured yogurt supplemented with an algae oil emulsion, J Dairy Res., 72(3), pp. 311.

36. Tarakci Z. and Kucukoner E. (2003), Physical, Chemical, Microbiological and Sensory Characteristics of Some Fruit Flavored Yoghurt, YYÜ Vet Fak Derg., 14(2), pp. 10-14.

37. Sandulachi E. (2020), Activitatea apei în produsele alimentare, Monografie, Chișinău, Editura Tehnica-UTM, pp. 55-61.

38. Domagała J. (2009), Instrumental texture, syneresis and microstructure of yoghurts prepared from goat, cow and sheep milk, Int J Food Prop., 12(3), pp. 605-615.

39. Costa M.P., Frasao B.S., Silva A.C.O., Freitas M.Q., Franco R.M. (2015), Cupuassu (Theobroma grandiflorum) pulp, probiotic, and prebiotic: Influence on color, apparent viscosity and texture of goat milk yogurts, J Dairy Sci., 98(9), pp. 5995-6003.

40. Misbach M., Sangeen N., Jabeen R. (2013), Antibacterial activity of fruits againstr Escherichia coli, ARPN Journal of Agricultural and Biological Science, 8(3), pp. 258-263.

41. Konate K., Hilou A., Mavongou J.F. (2012), Antimicrobial activity of polyphenol-rich fractions from Sida alba (Malvaceae) against cotrimoxazol-resistant bacteria strains, Annals of Clinical Microbiology and Antimicrobials, 11(5), pp. 69-80.

42. Mallesha S.R., Selvakumar, Jagannath, J.H. (2010), Isolation and identification of lactic acid bacteria from raw and fermented products and their antibacterial activity, Recent Research in Science and Technology, 2, pp. 42-46.

43. Widodo T., Tiyas T.T., Nosa S. A. (2013), Fermented goat milk and cow milk produced by different starters of lactic acid bacteria: Quality studies, J AgrSci Tech A., 3, pp. 904-911.

44. Bakirci I. and Kavaz A. (2008), An investigation of some properties of banana yogurts made with commercial ABT-2 starter culture during storage, International Journal of Dairy Technology, 59(3), pp. 216-221. 
45. Limei C., Vigneault C., Raghavan V.G.S., Kubown S. (2007), Importance of the phytochemical content of fruits and vegetables to human health, Stewart Postharvest Review, 3, pp. 1-5.

46. Tolic M.T. (2015), Antioxidant Properties of Chokeberry Products, Food Technol. Biotechnol., 53(2), pp. 171-179.

47. Gao X., Ohlander M., Jeppsson N., Bjork L., Trajkovski V. (2015), Changes in antioxidant effects and their relationship to phytonutrients în fruits of sea buckthorn (Hippophaerhamnoides L.) during maturation, J Agric Food Chem, 48(5), pp.1485-1490.

48. Chouchouli V., Kalogeropoulus, N., Konteles S.J., Karvela E., Makris D.P., Karathanos V.T. (2013), Fortification of yogurts with grapes (Vitisvinifera) seed extracts, LWT-Food Sci. Technol., 53, pp. 98-103.

49. McDougall G.J., Austin C.,VanSchayk E., Martin P. (2013), Salal (Gaultheria shallon) and aronia (Aroniamelanocarpa) fruits from Orkney: Phenolic content, composition and effect of winemaking, Food Chem., 205, pp. 239-247.

50. Koponen J.M., Happonen A.M., Matt ila PH, Torronen A.R. (2007), Contents of anthocyanins and ellagitannins in selected foods consumed in Finland, J Agric Food Chem., 55(4), pp. 16121619.

51. Wallace T.C., Giusti M.M. (2010), Determination of color, pigment, and phenolic stability in yogurt systems colored with nonacylatedanthocyanins from Berberisboliviana L. as compared to other natural/synthetic colorants, J. Food Sci, 73(4), pp. 241-248.

52. Genovese M.I., Pinto M.D.S., Goncalves A.E.D.S. (2008), Bioactive compounds and antioxidant capacity of exotic fruits and commercial frozen pulps from Brazil, Food Science and Technology International, Thousand Oaks, 14(3), pp.207-214

53. Hassimitto N.M.A., Genovesse M.I., Lajolo F.M. (2005), Antioxidant activity of dietary fruits, vegetables, and commercial frozen fruit pulps, Journal of Agricultural and Food Chemistry, Washington, 53(8), pp.2928-2935.

54. Oh H.S., Kang S.T. (2015), Quality Characteristics and Antioxidant Activity of Yogurt Supplemented with Aronia (Aronia melanocarpa) Juice, Prev Nutr Food Sci., 21(4), pp. 330 337.

55. Moltó-Puigmartí C., Permanyer M., Castellote A. I., López-Sabater M. C. (2011), Effects of pasteurisation and high-pressure processing on vitamin $\mathrm{C}$, tocopherols and fatty acids în mature human milk, Food Chemistry, 124(3), pp. 697-702.

56. West C.E., Eilander A., Lieshout M. (2002), Consequences of revised estimates of carotenoid bioefficacy for dietary control of vitamin A deficiency in developing countries, The Journal of Nutrition, 132(9), pp. 2920S-2926S.

57. Bzducha A., Wolosiak R. (2006), Synergistic effect of antioxidant activity of casein and its enzymatic hydrolysate in combination with ascorbic acid and $\beta$-carotene in model oxidation system, Acta Sci. Pol., Technol. Aliment, 5(1), pp. 113-133.

58. Mercadante A. Z. (2008), Carotenoids in foods: Sources and stability during processing and storage, Food Colorants - Chemical and Functional Properties, 10, pp. 213-240.

59. Guz E., Novitskaya E., Kalenik T., Levochkina L., Piekoszewski W. (2017), The influence of vegetable puree containing carotenoids on the nutrient composition and structure of milk yoghurt, Int. J. Dairy Technology, 71(1), pp. 89-95.

60. Giufrida D., Torre G., Dugo P., Dugo G. (2013), Determination of the carotenoid profile in peach fruits, juice and jam, J. Fruits, 68(1), pp. 39-44

61. Remya P.R., Sharon CL., Aneena E.R., Seeja T.P., Shahanas E. (2019), Standardization and Quality Evaluation of Jackfruit based Low Fat Yogurt, Asian J Dairy Food Res, 38(2), pp. 93-97

62. Punnagaiarasi A., Rajarajan G. and Elango A. (2016) Assessing the sensory quality of stirred papaya yoghurt during storage period, International Journal of Science and Nature. I.J.S.N., 7, pp. 878-880.

63. Hossain M. N., Fakruddin M. and Islam M. N. (2012), Quality comparison and acceptability of yoghurt with different fruit pulps, J Food Process Technol, 3(8), pp. 1-5.

64. Vahedi N., Tehrani M.M., Shahidi F. (2008), Optimizing of fruit yoghurt formulation and evaluating its quality during storage, Am-Eurasian J Agric Environ Sc., 3(6), pp. 922-927. 